\title{
ANAESTHESIOLOGICAL MAINTENANCE OF PATIENTS WITH OBESITY
}

\author{
Margarita Vyzhigina, Viktor Titov, Svetlana Zhukova, and Oksana Kurilova \\ National Research Centre of Surgery, Russian Academy of Sciences, 2 Abrikosovsky per., 119991, Moscow, RUSSIA
}

Communicated by Rafails Rozentāls

\begin{abstract}
Pathophysiological features of morbid obesity and the associated functional-anatomical changes in an organism demand the special approach to anaesthesiological maintenance. Methods of anaesthesiological protection and maintenance of effective gas exchange in morbide obesity patients have been proved. Anaesthesias for 110 patients have been analysed. Multicomponent anesthesia with traditional and combined artificial lung ventilation (ALV) (IPPV+HFJV) (intermittent positive pressure ventilation and high frequency jet ventilation) was used. Since 2000, morbid obesity patients receive intubation only with fibrobronchoscope with self breathing under local anesthesia. In IPPV for morbid obesity patients high peak pressure in airways, low V/Q, and low $\mathrm{PaO}_{2}$ occurs. Technology of combined ALV (IPPV+HFJV) has led to pressure decrease in airways and to effective arterial oxygenation improvement, intrapulmonary shunt has decreased. Retrospective analysis of anesthesia components revealed that the applied anaesthetic doses correspond to calculations on ideal body weight, and not true weight. Thus, anaesthesiological maintenance of operated patients with morbid obesity requires trachea intubation with fibroscope under local anaesthesia with self-breathing; high efficiency of ALV methods, allowing lower pressure in airways and high oxygenation (IPPV+HFJV), which provides effective gas exchange; doses correction of intravenous anaesthetics for due body weight is required.
\end{abstract}

Key words: morbid obesity, anaesthesiological maintenance, traditional lung ventilation, high frequency ventilation, tetrapolar integrated reography of a body.

\section{INTRODUCTION}

Presently, about $30 \%$ of the adult population of economically developed countries suffer from obesity (Bray, 1998; Бутрова, 2000). About 1-5 \% persons have body weight exceeding $170 \%$ of the norm, that is, suffering from morbid obesity (Buckley 1994), and the numbers are progressively increasing. The rate of growth is about $10 \%$ from each ten years (Hodge et al., 1996).

Obesity has social value as it essentially reduces the quality of a life and expectancy (Deitel, 1990; Бутрова, 2000). Especially dangerous is morbid obesity, as the death rate in the age of 25-35 years is 12 times more for people with normal weight (Drenick et al., 1980). Most of all the cardiovascular system at obesity suffers. The risk of disease and death rate from cardiovascular diseases (Bjorntop, 1988) significantly increases, particularly atherosclerosis and arterial hypertensia (Herrera et al., 2000). Obesity is related to frequency of a carbohydrate exchange infringement, including II type diabetes (Herrera et al., 2000). Arterial hypertensia, II type diabetes, an atherosclerosis and ischemic heart disease are indirectly also associated with obesity (DeFronzo et al., 1991).

Anaesthesiological maintenance at patients with obesity has a number of features related to surplus of adipose tissue.
Obesity and the associated metabolic features can lead to a change of pharmacokinetics and pharmacodynamics of the drugs applied to carrying out anaesthesiological maintenance (Guillermo et al., 2000). One of major challenges is maintenance of passableness of respiratory ways, including trachea intubation, and adequate ventilation at stages of anesthesia. Obesity patients often have complicated anaesthesia maintenance, operative intervention and postoperative period. The intraoperative and postoperative death rate of patients with obesity is considerably higher, than for patients with normal body weight. In gastroenteric operations the path death rate of patients with obesity is $6.6 \%$ vs $2.6 \%$ for patients with normal weight (Postlethwait et al., 1992).

Considering the above, there is a need to assess the various methods of multicomponent anaesthesia, to investigate the influence of various modes of artificial lung ventilation (ALV) on gas-exchange function of lungs and to analyse some features of water-electrolyte balance for obese patients.

The purpose of the research was to develop a basic concept of maintenance of effective and safe anaesthesiological protection, development of multicomponent methods of anaesthesia, respiratory support and methods of intraoperative 
monitoring of vital functions with use of modern technologies during operations at patients with obesity.

The following objectives were raised: 1) to develop efficient, safe and controllable multicomponent techniques of anaesthesiological protection for patients suffering from obesity, adequately maintaining a sufficient level of gas exchange during operation; 2) to develop methods of maintenance of passableness of respiratory ways and variants of respiratory support at stages of anaesthesia and operation with use of traditional and special ALV methods with the purpose of their adaptation to features of an organism of patients with obesity and in view of pathophysiological features of gas exchange and blood circulation in patients with obesity; 3) to study features of infusion-transfusion therapy in patients, suffering from obesity; 4) to estimate informatively both the expediency of application of invasive and noninvasive methods of intraoperative monitoring.

\section{MATERIAL AND METHODS}

Research had partially a retrospective character as data were collected on operated patients during with 1992 for 2003 at the National Research Centre of Surgery Russian Academy of Medical Science (NRCS RAMS, Moscow, Russia). A total of 110 patients suffering from obesity were investigated. The age of patients was 16 to 65 years (on average, $42.6 \pm$ $0.9)$. Most operative interventions were vertical gastroplastyc (44 cases), vertical gastroplastyc with cholecystectomy (15 cases), herniasection with abdominoplastyc (12 cases). The most widespread pathology accompanying obesity were diseases of cardiovascular and respiratory systems.

Patients were grouped depending on index of body weight (IBW), the basic anaesthetic agent and techniques of respiratory support. According to IBW, 88 patients suffered from morbid obesity and 22 patients had superfluous weight but did not suffer from morbid obesity. Depending on the core anaesthetic agent at stage of a induction cases were allocated in three groups: basic induction agent was thiopentale (53 persons), ketamine (45 persons) and propofole (12 persons); depending on the core anaesthetic agent for maintenance of anaesthesia: nitrous oxide-oxygen mix (36 persons), thiopentale (32 persons), ketamine (34 persons) and propofole (8 persons). Depending on technique of respiratory support patients were divided as: patients on IPPV N2O:O2=2:1, IPPV and oxygen-air mix $(\mathrm{FiO} 2=0.8 \pm 0.05)$ and patients applied the combined technique technique-intermittent positive pressure ventilation and high frequency jet ventilation (IPPV+HFJV).

By using invasive and noninvasive techniques gas exchange and system haemodynamics were studied. Haemodynamic measurements were made on a domestic monitor complex MX-04 and with use of computer monitor complex Diamant-R. System arterial pressure (AP) and the central venous pressure (CVP) were recorded by gauges of a complex, by which artery radialis and one of the central veins were punctured by a needle (Braun, Germany). $\mathrm{PCO}_{2}, \mathrm{PO}_{2}$, saturation, lactate and electrolytes of the arterial and mixed venous blood were determined using a device ABL-system 625 (Radiometre, Denmark). The level of hormones in blood was determined by radioimmunological method in laboratories of immunology and regulation mechanisms in NRCS RAMS.

For calculation of haemodynamic parameters, gas exchange, oxygen transport functions of blood and statistical processing a personal computer was used. Statistical reliability of results was estimated on the basis of the t-test with calculation of standard deviations. Significant differences were defined by Student-criterion $(P<0.05)$. The preoperative inspection report consisted of two basic parts. The first, obligatory part included a complex of research, given to all patients, suffering from obesity, without association to an accompanying pathology. It included: gathering of anamnesis data on history of the core and accompanying diseases and allergology anamnesis; the general clinical analysis of blood and urine; definition of blood group and Rhesus factor; the analysis of blood on AIDS, syphilis and hepatitis; biochemical tests of blood, including lipid structure; coagulogram; external breath function; radiology of lungs; electrocardiogram; definition of ASA risk; estimation of difficult intubation risk on Mallampati. With the purpose of specification of degree of expressiveness of the accompanying pathology revealed in the first investigation phase, the additional report included: 1) glycaemic profile, 2) Holther monitoring, 3) ECHO-KG with definition of pressure in a pulmonary artery, 4) rentgenography of a Turkish saddle, 5) oesophagogastroduodenoscopy (OGDS), 6) ultrasonic of internal organs, 7) dopplerographic investigation of deep veins of shins and a basin.

The choice of drugs for premedication was carried out on the basis of principles of polycomponents and equation, in view of the basic and accompanying pathology, and regarding features of the patients connected with superfluous weight of a body. On the previous night, for 40-60 min before operation, patients received diazepam 5-10 mg, tazepam 10-20 mg or phenazepam $0.5-1 \mathrm{mg}$, in a combination with antihistamine drugs (Dimedrol 50-100 mg or suprastine $25-50 \mathrm{mg}$ ), at indication - an antidepressor. Holynolitic (metacine or atropine) was given in premedication on the day of operation $\mathrm{i} / \mathrm{m}$ in a dose based on weight of patient of $0.03 \mathrm{mg} / \mathrm{kg}$. Narcotic analgetics in premedication were not included with the exception in possible cases of depression of breath. $200 \mathrm{mg}$ of $\mathrm{H}_{2}$-blocker Hystodile was applied in premedication $\mathrm{i} / \mathrm{m}$ for the night and for 40-60 min before operation. Originally Hystodile was appointed to patients with erosive gastritis in the anamnesis. Further, $\mathrm{H}_{2}$-blocker was included in premedication to all patients.

\section{RESULTS}

Application nitrous oxydide to patients with morbid obesity is accompanied with development of hypoxemia, hypercarbia, blood circulation depression by $2 \mathrm{x}$ on high pressure in 
airways (up to $60 \mathrm{cmH}_{2} \mathrm{O}$, on occassion) and low respiratory volume at the rate of $4-6 \mathrm{ml} / \mathrm{kg}$ body weight. Attempts to alleviate oxygenation deficiency by increasing minute volume ventilation (MVV) are not effective in association with a high pressure in respiratory ways.

Duration of the period of induction in carrying out intubation with use of a straight laryngoscopy was $13.6 \pm$ 0.9 min, similar to the time of trachea intubation on FBS preparations. Saturation during intubation on FBS was 98.4 $\pm 0.3 \%$ (on a background of constant inhalation $\mathrm{O}_{2}$ ), using a straight laryngoscopy-94.6 $\pm 0.5 \%(P<0.05)$.

It is certain that among patients with morbid obesity and heavy accompanying diseases, there is a category of patients, resistant to increase of a level of gas exchange due to increase in fraction of oxygen in a respiratory mix. This in our study applied to 12 of 88 patients with morbid obesity $(13.6 \%)$. The patients had severe restrictive character of infringements of external breath with respiratory failure II-III $\left(\mathrm{Sat}=91.2 \pm 0.4 \%\right.$ and $\mathrm{P}_{\mathrm{k}} \mathrm{O}_{2}=73.4 \pm 1.9 \mathrm{mmHg}$, at $\mathrm{FiO} 2=$ 0.21 ; in conditions IPPV: $\mathrm{P}_{\mathrm{k}} \mathrm{CO}_{2}=39.2 \pm 3.8 \mathrm{mmHg}$, $\mathrm{SkO} 2=94.4 \pm 0.8 \%$, at $\mathrm{FiO} 2=0.8 \pm 0.05)$, suffering from morbid obesity. These patients need special methods ALV, which allow lowering the respiratory volume and pressure in airways. In this regard, use of combined technique ALV $($ IPPV + HFJV) allowed to reach optimum arterial oxygenation (to increase $\mathrm{PaO} 2$ from $88.8 \pm 1.5$ up to $156.2 \pm 3.2$ $\mathrm{mmHg}, P<0,05$ in comparison with IPPV at FiO2 $=0.7-$ 1.0 ), to lower pressure in respiratory contour (from $34.3 \pm$ 3.2 up to $21.3 \pm 1.5 \mathrm{~cm} \mathrm{H}_{2} \mathrm{O}, P<0.05$ in comparison with IPPV at $\mathrm{FiO} 2=0.7-1.0$ ) to lower a level of the intrapulmonary shunt from $13.7 \pm 2.8$ up to $11.7 \pm 1.3 \%$ cardiac output $(\mathrm{CO})$ and to increase V/Q from $0.6 \pm 0.2$ up to $0.9 \pm$ 0.1 and to stabilisate haemodynamics.

Volume and speed of infusion-transfusion therapy (ITT) were calculated on ideal weight of a body, in view of bleeding volume and speed.

\section{DISCUSSION}

The techniques of anaesthesia considered in the work possess sufficient efficiency in the way of anaesthesiological protection of patients suffering from obesity. The present research shows the relevance of using ketamine and propofol on the basis of nitrous oxide and thiopentale in patients suffering from morbid obesity is certain. Anaesthesia by nitrous oxide demands in morbid patients during carrying out ALV with a respiratory mix with high maintenance of oxygen causes a need for additional introduction of hypnotic agents because of a low concentration nitrous oxide in the respiratory mix at separate stages of operation. Considering that nitrous oxide does not possess a direct damaging action on respiratory system, on the one hand, and that the great bulk of postoperative complications has been connected with the respiratory system (atelectases, pneumonia), on the other hand, it is possible to assume that these complications are connected with the limited mobility of a dia- phragm owing to hyperinflation loops of intestines. This fact indirectly proves to be true by longer stay of patients in reanimation $(2.1 \pm 0.3$ days $)$, in comparison with the other groups. Also, nitrous oxide aggravates respiratory mechanisms leading to hypoxia, which to an even greater degree can aggravate hypoventilation in obese patients. The technique of anaesthesia on the basis of thiopentale provides a necessary level of anaesthesiological protection, but to a lesser degree in comparison with ketamine and propofole, and is characterised by more expressed fluctuations of haemodynamic parameters and stress-hormone level in reply to operational stress. Anaesthesia on the basis of propofole demands introduction of sufficiently high doses of narcotic analgetics. The use of propofole as the basic hypnotic agent possesses a high degree of controllability, but on the other hand limits the anaesthesiologist in a choice of vegetostabilisation drugs (droperidole, clonidine), because of the potential danger of a hypotension. In these conditions the technique shows a high degree of protection from operational stress. The use of ketamine as the core anaesthetic agent is characterised by high haemodynamic stability and a low need in narcotic analgetics, and a sufficiently high degree of controllability of depth of anaesthesia.

The expediency of use of doses of preparations for carrying out of anaesthesia at a rate based on ideal weight of a body is certain. First of all this concerns the patients suffering from morbid obesity. On the basis of literature and research it is possible to conclude that optimum techniques of anaesthesiological protection of patients suffering obesity, are use of short-range preparations with non-organ metabolism.

Methods of maintenance of passableness of respiratory ways and respiratory support. Application of intubation trachea technique with use of fibrobronchoscope (FBS) as an intubation tubes conductor is preferable in laryngoscopy of patients with obesity. The given technique to a lesser degree influences on the larynx reflex zones and a root of language, than a straight laryngoscopy. It is associated with a short duration of manipulation on a background of local anaesthesia, and less trauma. The use of the given technique of intubation of tracheas allows independent breathing of the patient, and hence, apnoe is avoided, which inevitably is present in carrying out of a straight laryngoscopy and in case of difficult intubation can be long.

Difficulties of maintenance of adequate gas exchange in patients with obesity are connected with necessity of carrying out ALV in high respiratory volumes, a high fraction of oxygen. The greatest difficulties of maintenance of adequate ventilating support are in morbid patients with significant ventilating infringements, mainly on restrictive type. Optimisation of methods of ALV in these patients is caused by impossibility of a further increase in the respiratory volume, connected with a high pressure in respiratory ways and increases in fraction of oxygen for maintenance of adequate gas exchange. A search is needed for special methods of ALV allowing to lower respiratory volume and pressure in airways. In this connection use of combined technique 
ALV (IPPV + HFJV) allowed to reach optimum arterial oxygenation, to lower pressure in respiratory contour, to lower the level of the intrapulmonary shunt, to increase V/Q and to stabilise haemodynamics.

Infusion-transfusion therapy. In the analysis of infusiontransfusion therapy (ITT) and mutual relations of water sectors of an organism patients were divided into three groups: patients who needed transfusion of components of blood during operation (5 persons), patients who needed transfusion of only crioplasma ( 9 persons) and patients who did not ransfusion of components of blood (11 persons). Volume and speed of ITT were calculated based on ideal weight of a body, in view of bleeding volume and speed. ITT maintenance in patients with obesity considered low resistance to water loadings of this category of patients. ITT tactic for obesity patients as a whole is constructed by traditional principles, however, it is necessary to consider that indemnification perspiration losses should be oriented on ideal weight of a body. Application in the structure of ITT, the components of blood on a background of significant introduction of crystalloides in response to bleeding creates preconditions to increase the volume of extracellular liquid.

Intraoperation haemodynamic monitoring. Intraoperation haemodynamic monitoring of the vital functions of patients with obesity is the most serious problem. Necessity for continuous control over a number of systems of an organism and the accompanying technical complexity for its maintenance in obese patients need search for adequate and safe techniques of supervision. Presence of a serious accompanying pathology is demanded in patients with obesity and function of the vital systems needs control during the entire period of operative intervention. On the one hand, haemodynamic control with use of traditional nonivasive measurement of arterial pressure becomes complicated by obvious technical complexity associated with necessity of use special cuffs of large size and by high error of parameters for the given technique in patients with obesity (Buckley, 1998; Guillermo et al., 2000). On the other hand, the degree of monitoring invasivity should correspond to weight of an accompanying pathology and operative intervention. Proceeding from the aforesaid, it is reasonable to pay attention to alternative methods of haemodynamic estimation. During search of alternative nonivasive methods of haemodynamic investigation, we used the domestic monitor complex "Diamant-R" working on the basis of a personal computer with use tetrapolar integrated reography of a body and realized on the basis of modern computer technologies. The obvious advantages of the technique was that it was noninvasive and informative. A sufficiently high enough correlation between the compared parameters of tetrapolar integrated reography and invasive techniques of measurement implies their good comparability. Thus, it is possible to conclude, that reomonitoring with use of device "Diamant-R" of firm of Joint-Stock Company "Diamant" has proved to be informative, authentic and a visual teaching method of intraoperation haemodynamic control.

\section{REFERENCES}

Bray, G.A. (1998). Obesity: A time bomb to be defused. Lancet, 18, $160-161$.

Buckley, F.P. (1994). Anaesthetic management of the obese patient. In Anaesthesia, $2^{\text {nd }}$ ed. Nimmo, W.S., Rowbotham, D.J., Smith, G. (eds.). Oxford, Blackwell Scientific, pp. 1148-1160.

Buckley, F.P. (1998). Anesthesia and obesity and gastrointestinal disorders. In Clinical Anesthesia. Barash, P.G. (ed.). Philadelphia, pp. 1170-1183.

Bjorntop, P. (1988). The association between obesity, adipose tissue distribution and disease. Acta. Med. Scand., 723(suppl.), 121-134.

Deitel, M. (1990). Morbid obesity. Ann. RCPSC (Royal College of Physicians and Surgeons of Canada), 23, 241-246.

DeFronzo, R.A., Ferrannini, E. (1991). Insulin resistance, a multifaceted syndrome responsible for NIDDM, obesity, hypertension, dislipidemia and atherosclerotic cardiovascular disease. Diabetes Care, 4(3), 173-194.

Drenick, E.J., Bale, G.S., Seltzer, F. (1980). Excessive mortality and causes of death in morbidly obese men. JAMA, 243, 443-445.

Guillermo, D.C., Borunda, D., Gonzalez, R. (2000). Anesthesia for morbidly obese patients. In Update: Surgery for the Morbidly Obese Patient. Deitel, M. (ed.). Toronto, pp. 95-104.

Herrera, M.F., Lozano-Salazar, R.R., Gonzalez-Brranco, J. (2000). Diseases and problems secondary to massive obesity. In Update: Surgery for the Morbidly Obese Patient. Deitel, M. (ed.). Toronto, Canada, pp. 55-62.

Hodge, A.M., Dowse, G.K., Gareeboo, H. (1996). Incidence, increasing prevalence, and predictors of change in obesity and fat distribution over 5 years in the rapidly developing population of Mauritius. Int. J. Obes. Relat. Metab. Disord., 20(2), 137-146.

Postlethwait, R.W., Johnson, W.D. (1992). Complications following surgery for duodenal ulcer in obese. Arch. Surg., 105, 438.

Бутрова С.А. Ожирение (этиология, патогенез, классификация) [Obesity (ethiology, pathogenesis, classification)]. В кн. Ожирение. Метаболический синдром. Сахарный диабет 2 типа (под ред. Дедова И.И.), Москва, с. 5-6.

\section{ADIPOZO PACIENTU ANESTEZIOLOG̣ISKĀ APRŪPE}

Patoloğiska adipozitāte ir saistīta ar organisma funkcionāli anatomiskām pārmain̄ām, un tā prasa speciālu pieeju, veicot anestēziju. Darba mērkis bija izveidot adipozo pacientu drošu anestezioloǵiskās aprūpes konceptu, ietverot respiratoro atbalstu, vitālo funkciju monitoringu, kā arī attīstot anestēzijas daudzkomponentu metodi. Veikta anestēzijas analīze 110 pacientiem, ietverot škiiedroptisko trahejas intubāciju nomodā, gāzu apmaiņu, plaušu ventilācijas vispusīgu izvērtēšanu, hemodinamisko monitoringu, anestētiķu dozēšanu, ņemot vērā pacientu reālo svaru. Atzin̄igi novērtēta reomonitoringa ierīces „Diamant - R” praktiskā izmantošana hemodinamikas kontrolei. 